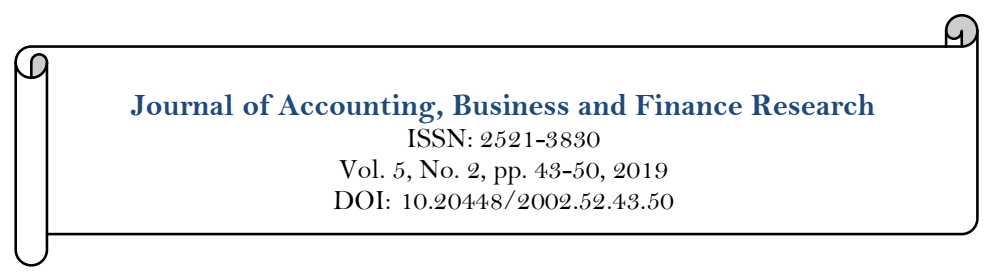

$\checkmark$ updates

\title{
A Literature Review on the Study of Income Distribution, Education and Education Return Rate - Based on Family Background and Gender Differences
}

\author{
Qiong Han $^{1}$ \\ ${ }^{\prime}$ Doctoral Student, School of Economics, Central University of Finance and Economics, Beijing, China, and Lecturer, Yunnan College of \\ Business Management, China \\ Email:qiong84629@163.com
}

\begin{tabular}{|c|c|}
\hline Abstract & \\
\hline $\begin{array}{l}\text { The study of income distribution, education input and education return rate } \\
\text { has always been a hot topic in the theoretical circle. Most of the existing } \\
\text { researches have drawn a conclusion that there is a significant positive } \\
\text { correlation between the years of education and the income level. There is a } \\
\text { two-way causal relationship between income distribution and education. In } \\
\text { addition, the distribution of education and the rate of return on education } \\
\text { will also have an impact on education. This paper aims to focus on the } \\
\text { impact of gender differences in income distribution on education based on } \\
\text { previous research, while focusing on the distribution of education and the } \\
\text { rate of return on education in different genders. Based on the specific } \\
\text { quantitative indicators of the differences, some theoretical support and policy } \\
\text { recommendations on education and education reform are given. }\end{array}$ & $\begin{array}{l}\text { Keywords: } \\
\text { Income distribution } \\
\text { Education distribution } \\
\text { Education return rate } \\
\text { Family background } \\
\text { Gender difference. } \\
\text { Licensed: } \\
\text { This work is licensed under a } \\
\text { Creative Commons Attribution } 4.0 \\
\text { License. } \\
\text { Publisher: } \\
\text { Scientific Publishing Institute }\end{array}$ \\
\hline
\end{tabular}

Funding: This study received no specific financial support.

Competing Interests: The author declares that there are no conflicts of interests regarding the publication of this paper.

\section{Introduction}

With the advent of the information age, education plays an increasingly important role in personal growth and development. Can education change the destiny of a person and let the students of the cold door get out of the crowd? The data in recent years seems to keep telling people that it is increasingly difficult for children whose families are born in poverty to change their own destiny through education and open up the upward flow. What factors affect education? Is it possible to break all the possibilities of a person's success? Can education help the poor students who are not good at providing the possibility of changing their destiny? Based on this idea, we began to think about this article. According to the existing research, there are mainly three factors that affect education.

\section{Income Distribution}

In 1974, American economist Jacob Mincer found that there was a significant positive correlation between years of education and income levels, which was considered the earliest study in the field. Galor and Zeira (1993) have a ground breaking role in studying the literature on income distribution for educational inequality. They examine the impact of initial income distribution on the distribution of education, and for the first time put forward the idea that income equality promotes human capital accumulation. It is believed that because the borrowing market is incomplete, the equalization of income is more conducive to the education opportunities of the poor who cannot raise education costs through borrowing, which in turn affects the distribution of education. Early literature on income distribution and education inequality, Schultz (1960), Becker and Chiswick (1966), Mincer (1974) and Beckers (1975) respectively confirmed by model that per capita education and educational distribution affect income distribution. 
Becker and Chiswick (1966), Chiswick (1971), Tinbergen (1972) and Winegarden (1979) use regional data from the United States and cross-sectional data from 32 countries to conclude that there is a clear positive correlation between educational inequality and income inequality. Sex, that is, improvement, that is, education inequality can effectively alleviate the current situation of income inequality. Psacharopoulos (1977) used cross-sectional data to measure the difference coefficient between different levels of education enrollment, and found that the educational inequality variable was significantly negatively correlated with the Gini coefficient, and the degree of educational inequality explained the variation of income distribution by more than $20 \%$. Benabou (1996) and Aghion and Howitt (1999) pay more attention to income redistribution, and believe that redistributive policies can help regulate income inequality and thus affect people's investment in education. Education is the most important way to obtain human capital, and the interpretation of income inequality is largely related to educational inequality. Park (1996) uses cross-sectional data from 59 countries, with the standard deviation and coefficient of variation of the average years of education of workers as the inequality of education, and the income share and income of the $20 \%$ of the population with the highest Gini coefficient. The income share of $40 \%$ of the population is a variable of income inequality. It is empirically concluded that the increase in educational inequality will increase income inequality. The above literature mainly studies the relationship between income distribution inequality and education inequality. It is confirmed by research that there is a two-way causal relationship between the two, that is, the uneven income distribution affects the education input, and the education investment is small, which leads to lower income level.

Benabou (1994) used the mathematical model to study the data of different income families and found that the amount of wealth is a direct factor affecting the individual's education. The return rate of education for poor families is significantly lower than that of wealthy families. Barro and Lee (2001) used empirical analysis to study multiple data. The results show that the income gap between countries will accelerate the development of developed countries and hinder the development of underdeveloped countries. At the same time, uneven income distribution will bring the difference in the accumulation of human capital. Sylwester (2000) explores the perspective of education public investment and income distribution, and finds that the differences in income distribution between different regions will affect the investment of local governments, which will lead to differences in education input between different regions.

$\mathrm{Lu}$, Chen, and Wan (2005) used the distribution lag model to draw conclusions that the income gap has a non-linear effect on education. Wang and Gang (2005) found through research that the main reason for the widening income gap between urban residents in China is that the per capita education level is uneven. Compared with low-income people, the educational opportunities of high-income people have increased significantly, which in turn has aggravated the income gap.

Liu and Xu (2007) selected the data from 1990 to 2005. Through empirical analysis, it was found that the education gap between urban and rural residents in China is mainly reflected in the gap in education investment, and the main factor limiting the investment in education is the income gap between urban and rural residents. Wangs and $\mathrm{Xu}$ (2008) calculated the Gini coefficient of the per capita years of education in the country. After decomposing the data by region, the conclusions are consistent with Liu and Xu (2007) that is, the income inequality between regions will be Education spending has an impact on education inequality.

As far as China's current development status is concerned, studying the relationship between income distribution gap and education inequality and the internal mechanism can help to give policy recommendations from the perspective of education promotion to narrow the current income distribution gap in China.

\section{The Distribution of Education}

Domestic scholars' research on income distribution and education is mostly discussed from the perspective of education return rate and education expansion. However, there are relatively few studies on the uneven distribution of education on education acquisition. The uneven distribution of education mainly depends on regional, urban and rural and urban internal differences, and there are also studies from a gender perspective.

Chen, Lu, and Jin (2004) found through empirical evidence that the main reason for the income gap in various regions of China is that the education development in the provinces is uneven, and the proportion of higher education populations in various regions has begun to converge, and the balanced development of education will help improve the income gap between regions. Chens, Wang, and Wei (2004) found the correlation between education and wages and the increase in the rate of return of education by decomposing the change equation of wage income distribution and using the income distribution data of urban residents in China from 1995 to 1999 . Inequality in wage income, and the mitigation of income inequality can be achieved by reducing educational inequality.

Yang, Huang, and $\mathrm{Li}(2008)$ found that uneven income distribution leads to education inequality, and the improvement of education inequality cannot promote the narrowing of income distribution gap. There is no simple linear relationship between education inequality and income distribution gap. In the long run, the improvement of education inequality does not significantly reduce income inequality, but income inequality will have an impact on education inequality in the current period. Yangs and Huang (2010) have not reduced the income inequality, but the education expansion can effectively control the income distribution gap. The reduction of education inequality and the expansion of education are not enough. It is necessary to achieve a 
certain level of education expansion. The lower level of education inequality indicates that improving the income distribution gap by promoting education is a long process and needs continuous improvement. In particular, raising the level of education for low-income people can effectively solve the problem of widening income gaps in China. In view of the irrational structure of the labor market in the transmission of human capital, the large difference in the return rate between urban and rural education, and the irrational structure of education input, it is necessary to formulate a series of measures to guide correctly so that education equity and income equity can play a mutually reinforcing role.

$\mathrm{Yu}$ (2006) although the average length of education in China has been increasing year by year, the expansion of education has not improved the educational inequality in different family backgrounds.

Sun (2015) tested the two-way Granger causality between income distribution gap and educational inequality through a nonlinear ESTR model and presented a nonlinear dynamic relationship, which was expressed in the early stage, the relationship between income distribution and education was linear and nonlinear. Frequent conversions between linearities and later tend to be stable.

$\mathrm{Li}$ and $\mathrm{Ma}$ (2006) analyzed the gender wage differences of urban workers in China and set the high school education as the control group. Through research, it was found that human capital has a significant impact on the wage difference between men and women, and the strength of human capital plays with the academic qualifications. The gap increases and increases. They discussed the impact of gender differences and occupational differences on the income of urban workers, and found that the gender differences in urban workers have far greater impact on gender wages than between occupations.

$\mathrm{Li}$ and Song (2010) found in the study that from 1998 to 2007, market-oriented reforms led to a significant increase in the rate of return to education in the labor market. This change became the main cause of the increase in the income gap, while wages were in gender. The increase in the difference between industries and regions has further worsened the situation of uneven income distribution.

Yao, Huang, and $\mathrm{Su}$ (2007) found that compared with boys whose parents were less educated, the educational return rate of boys with higher education levels was about $35 \%$ higher; girls were about $28 \%$ higher. Ge (2007) analyzed the use of local linear model analysis. For all age groups and different education levels, women's education return rate is higher than that of men. Therefore, increasing investment in women's education is beneficial to alleviate the problem. The income gap between women and men.

The Mincer equation to estimate the rate of return on education in different regions of eastern, central and western regions, and found that the educational return rate in the central region was higher than that in the eastern and western regions. Berry and Glaeser (2005) found that the skill level and wage level showed a significant positive correlation, and the high income level promoted the aggregation effect of high-quality talents. Wang and Gang (2005) and others used a stratified linear model to derive the difference in educational returns between cities in the province than in the provinces.

Asadullah (2006) used Bangladeshi data to get a return on urban and rural education of 8.1 and 5.7, with significant differences. Hou (2004) used the OLS estimate added to the standard Mincer equation to derive the rural education return rate of $3.66 \%$, indicating that the rural workers' return on education is low. Zhao (2006) found that there is a close relationship between rural education return rate and non-agricultural economic development by adding non-agricultural economic factors and their interaction with education in the standard Mincer equation.

Some scholars have turned their attention to the inverted U-shaped relationship between the distribution of education and the average years of education. The study found that with the increase in the average number of years of education, the distribution of education will first increase and then decline. Londono (1990) and Ram (1990) first proposed the existence of Kuznets' "inverted U" relationship in the study of education distribution: with the continuous improvement of education level, education inequality will first rise, to reach the maximum when the value is, there is a tendency to gradually decline. Similarly, Ram (1990) used crosssectional data from 94 countries in his empirical analysis to conclude that the inflection point of the "inverted U" curve occurred approximately at a time when the average years of schooling were seven years. The empirical analysis by Thomas, Wang, and Fan (2003) also used cross-sectional cross-sectional data to arrive at a consistent result with Ram (1990) that is, there is an "inverted U" relationship between the level of educational development and the average years of education, and The inflection points of the "inverted U" curve are achieved in the average years of education 6-7 years, the difference is that their conclusions are more significant in the population over 15 years old. In addition, they use panel data to further confirm that the "inverted U" relationship between the education standard deviation and the average years of education is established. The relationship between the two will not change due to the choice of measurement methods and the change of control factors. Very strong and robust. Gregorio and Lee (2002) used data from 100 countries to add the lag factors of income factors and variables to the regression equation. The empirical analysis confirmed that the education distribution does have an "inverted U” curve, but its peak value and Ram (1990) is different, probably in the average years of education around 4.2 years.

Ashenfelter and Rouse (1998) found that the rate of return on education increased with the increase in years of education, and through empirical analysis, they obtained an education return of $12 \%$ for education 
years of 9 and 16 years, respectively. 8\%. This seems to explain why there are fewer people receiving higher education.

Gregorio and Lee (2002) argue that income distribution is related to people's average years of schooling and their distribution, and that education inequality increases income inequality. However, given the distribution of education, they found that the increase in average education time did not have a clear impact on income distribution.

$\mathrm{Li}$ and $\mathrm{Li}$ (2010) denied the existence of Kuznets' "U" relationship in China's income gap. They believe that the causes of China's income distribution gap are multi-faceted, mainly due to urban internal income gap and rural areas. The internal income gap and the change in the income gap between urban and rural areas correspond to economic growth factors, economic system transformation factors and policy factors.

Xing (2008) calculated the income distribution gap not only by the rate of return on education, but also by the distribution of education. Zhu (2003) believes that education has a positive effect on income, and this role will continue to increase as the level of education increases. Li (2005) In terms of the impact of human capital on household income and income distribution, existing research emphasizes that differences in education levels are key factors leading to long-term income disparities between China, between urban and rural areas, within cities, and within rural areas.

Chenn and Cao (2013) believe that the widening income gap between urban and rural areas and the widening of regional income gap are the most important reasons for the widening income gap in China. Among them, one of the most important factors affecting the widening income gap between urban and rural areas is the difference in government education investment. Because the government has obvious bias towards the city in the investment of education, in the city, the education funds are concentrated to those schools with certain advantages, thus causing huge differences in the quality of education between urban and rural areas and within the city. Differences lead to serious educational inequalities that will have a negative impact on long-term income distribution.

\section{The Rate of Return on Education}

Later studies used the standard Mincer equation to examine the quantitative relationship between income distribution and educational returns. The research focus is mainly on the impact of family background on the rate of return on education.

Papanicolaou and Psacharopoulos (1979) used the father's occupational status as a proxy variable for the family background, using the British GSS 1972 data to show a reverse relationship between the educational return rate and the father's occupational status. Welch (1979) found that when a large number of workers enter the labor market, the income of college graduates will drop sharply. Card and Lemieux (2001) used data from the United States, the United Kingdom, and Canada to estimate the rate of return on education and found that the return on education for young people of all ages was higher.

Altonji and Dunn (1996) used the sibling data of the US PSID and NLS data respectively to study and draw different conclusions. Both parents' educational level is used as a proxy variable for the family background. The NLS database concludes that neither the father nor the mother's education level has an impact on the child's educational rate of return. After distinguishing by gender, it is found that the mother's education level has a significant positive effect on the return rate of girls' education, and the education level of both father and mother has a positive effect on the return rate of the boy's education. The PSID database concludes that maternal education has a positive effect on the return on education for both boys and girls. After sex, the educational level of fathers and mothers has no effect on the return on education of girls, and the educational level of fathers and mothers has a positive effect on the return on education of boys. In Greece's (Patrinos, 1995) the father's educational level was used as a proxy for the family background to study its relationship with the rate of return to education. Patrinos found that the educational return rate of the children increased with the education of the father. Increasingly, San-Segundo found that an increase in the level of education of parents would increase the return on education for boys and girls.

Fan (2003) analyzes from the perspective of intergenerational overlap and finds that there is a clear positive correlation between the previous generation of human capital and the next generation of educational investment, that is, the higher human capital accumulation of the previous generation will bring the next generation of education. The high investment is reflected in the high accumulation of human capital in the next generation, which will directly affect the income level of the next generation.

Psacharopoulos and Patrinos (2004) found that the return on education in general shows that the rate of return to education will increase first and then increase with the increase of education level, especially in lowincome countries and middle-income countries. Secondary education has the lowest rate of return. Patrinos and Sakellariou (2006) studied the educational rate of return in Venezuela and found that the rate of return on women's education was $1.3 \%-3.5 \%$ higher than that of men.

Hou (2004) pointed out that the return rate of rural education is seriously lower than that of the city, which is the direct cause of the income gap between urban and rural areas in China. This will not be conducive to the education of the disadvantaged. Yuan and Zhang (2009) used their father's income as a family background agent when studying family background and university education return rate. They found that 
the return on education of children of middle- and high-income families was significantly higher than that of children of low-income families. Yuu and Zhou (2015) believes that the low-family background children are reluctant to invest in compulsory education because the rate of return after compulsory education is lower than that of children with high family background, rather than traditional credit constraints. It is a good explanation why the student loan policy does not fundamentally solve the problem of higher education for children of low-income families. Because of the differences in family backgrounds in education returns, children with low family backgrounds are unwilling to invest in higher levels of school education, resulting in a generally low level of education, which is difficult to move upward through education, and even if they accept High education, limited by family background, makes it difficult to get income that matches the education received. This will, to a certain extent, dampen the enthusiasm of low-family background children to invest in higher education, resulting in lower incomes for children with low family background Dilemma.

Huang and Yao (2009) used the 2003 Chinese urban household data to verify that the improvement of women's education level can increase income, thereby increasing the rate of return on education. Li and Ding (2003) show that the rate of return to education at all stages increases with the level of education. Wangg (2009) divided the education stage between rural and local labor, and found that the return rate of education in secondary and high school is higher in non-local labor, and the education of junior college and above increases the income level of local workers.

In addition, there are some literatures that explore the difference in the rate of return on education. Shiyan and Luo (2009) estimated the return on education of urban males and females by estimating the educational returns of different age groups in urban areas, and they all tend to decrease first and then increase with age.

$\mathrm{Lu}$ et al. (2005) used the simultaneous equations and the distribution lag model to examine the relationship between urban-rural income gap, education public investment and economic development. The conclusions show that the expansion of the short-term income gap has increased the income of the higherincome class. Opportunities make human capital accumulate. In the long run, the expansion of the income gap will reduce the acceptance of better education for low- and middle-income people, which is not conducive to the accumulation of human capital and cannot effectively improve the income distribution gap. Lihua and Wang (2006) because family education helps to improve the scores of college entrance examinations, under the condition that the credit market is imperfect, the unified college entrance examination scores will make the children of some low-income families with high talents and children with lower incomes of low-income families replaced.

In addition, scholars study the rate of return on education from the aspects of unit ownership, industry, and occupation. Most of the existing researches have studied the return on education from a macro perspective, and there are few literatures from the microscopic perspective. Zhang and Xue (2008) consider the measurement from the perspective of unit ownership, and use microscopic sampling data for quantitative analysis, and find that the state-owned sector has high income. The main reason for the other parts is the high stock of human capital, especially in the high income range, where the difference in human capital is the determining factor for the income gap.

Education is an industry with long investment and slow income. For those with high family background, it may reach the current level after several generations of accumulation. Therefore, they know the importance of education and understand that education needs long-term investment. And the process of slow income, and for those with low family background, it may be due to the lack of a deep understanding of education for several generations, and there is obvious short-sightedness and quick success in education investment, so they do not enjoy the return of education. Dividends, their offspring in education investment cannot be as firm and far-sighted as the descendants of high family background, resulting in the differentiation of education investment in children with high family background and children with low family background, which leads to income gap.

\section{The Literature Summary}

What affects education has always been the focus of the theoretical circle, because education is not only related to the future and destiny of the individual, but also to the rise and fall of a country or even a nation. In the modern world of knowledge, the role of education is immeasurable, for the lack of Family background, no other superior resources can rely on, can only rely on their own contemporary students, studying the return on education under the family background has a strong practical significance.

\subsection{Research on Relevant Theoretical Literature \\ 5.1.1. Income Distribution}

Most of the existing researches consider the inequality in education and the inequality of income distribution and the inequality of income distribution on the impact of education inequality. Research using empirical methods mostly uses the quantile regression equation, or explore the relationship between the two from the perspective of educational return. Most of the panel data and section data are used in data selection, especially using cross-section data. The existing research on the impact of income distribution on education 
has basically reached a consensus, that is, high income level - high education input - high income, low income level - low education input - low income. Moreover, the research focused on the one-way influencing factors between income distribution and education. There are not many two-way causal considerations between income distribution and education, and the conclusions are not consistent.

\subsubsection{Education Distribution}

The influence of education distribution on education is reflected in the difference of education distribution in regions, urban and rural areas, industry and gender. Due to the current status of China's education system, the differentiation of education returns is becoming more and more serious. The possible reason is the distribution of education in China. It is not reasonable enough, especially in different regions, different industries and between urban and rural areas, there is a difference between genders; the other is that the degree of education expansion is not enough and needs to be strengthened. In addition, due to the inverted Ushaped relationship between the distribution of education and the average years of education, the number of people investing in higher education has decreased, which in turn has led to differences in income distribution. The inverted U-shaped curve about the distribution of education has been controversial, and the relevant literature abroad has basically reached a consistent conclusion, and domestic research is still controversial.

\subsubsection{Return on Education}

The influence of family background on the return on education can basically lead to a more consistent conclusion that the return on education of children with high family background is generally higher than that of children with low family background. The reason for this phenomenon is that children with low family backgrounds are unwilling to invest in higher levels of school education, resulting in a generally low level of education, and it is difficult to achieve upward mobility through education. On the other hand, even if they accept higher Education, limited by family background, it is difficult to get income that matches the education received. This will, to a certain extent, dampen the enthusiasm of low-family background children to invest in higher education, leading to low-income background children falling into lower income.

\subsection{Main Research Methods}

The most commonly used methods for studying the rate of return on education are the standard Mincer equation, the cost-benefit method, the OLS estimation with the addition of control variables in the Mincer equation, and the instrumental variable method. The Mincer income equation is a good derivation of a significant positive correlation between income and education levels. However, the Mincer equation failed to eliminate the influence of personal endowment on income. Later scholars made necessary improvements to the Mincer standard equation in the study. The research in this paper attempts to add a control variable to the extended OLS estimation based on the standard Mincer equation.

\section{Main Ideas Based on Literature}

The high family background has a high rate of return on education and low on a low family background. Due to the combined influence of factors such as vision, pattern, environment and information, the family background is more accurate, and the investment in education is more efficient. Therefore, the educational return rate is higher than that of the low family background. Since the impact of education on income is a long process, the rate of return on education may decline in the short term, but in the long run, the rate of return to education will increase, while for those with low family backgrounds, it tends to be short-sighted or The limitations of the family background are somewhat eager for quick success, lacking a long-term perspective on educational choices, which in turn leads to low returns on education with low family backgrounds.

Throughout the previous research, the study of income distribution and return on education either considers the income inequality from the perspective of income inequality, or uses empirical methods to estimate the specific quantitative relationship between income distribution and return on education, although there are also The background and gender perspectives are discussed, but there are few related literatures, most of which are considered from a macro perspective. The difference between the idea of this paper and the previous research is to try to explore the microscopic perspective of the difference in parental income distribution in the family context. By combing the existing literature, we add the OLS of the control variable to the standard Mincer equation to estimate the father and mother in the family. The impact of the income level on the return on education of children, through the estimation of the overall sample and the split by gender, respectively, the degree of influence of the income level of fathers and mothers on the educational return rate of children of different genders, according to the income level of parents The extent of the impact of the rate of return on education, and the provision of targeted recommendations and opinions to improve the educational return of children by improving the income level of parents in the family. 


\section{References}

Aghion, P. H., \& Howitt, P. (1999). Endogenous growth theory. Cambridge, Mass: The MIT Press.

Altonji, J. G., \& Dunn, T. A. (1996). The effects of family characteristics on the return to education. The Review of Economics and Statistics, 78(4), 692-704.

Asadullah, M. N. (2006). Returns to education in Bangladesh. Education Economics, 14(4), 453-468.

Ashenfelter, O., \& Rouse, C. (1998). Income, schooling, and ability: Evidence from a new sample of identical twins. The Quarterly Journal of Economics, 113(1), 253-284.

Barro, R. J., \& Lee, J. W. (2001). International data on educational attainment: Updates and implications. oxford Economic Papers, 53(3), 541-563.

Becker, G. S., \& Chiswick, B. R. (1966). Education and the distribution of earnings. The American Economic Revierw, 56(1/2), 358-369.

Beckers, G. S. (1975). Human capital: A theoretical and empirical analysis with special reference to education (2nd ed.). New York: National Bureau of Economic Research.

Benabou, R. (1994). Education, income distribution and growth: The local connection: National Bureau of Economic Research.

Benabou, R. (1996). Equity and efficiency in human capital investment: The local connection. The review of Economic Studies, 63(2), 237-264.

Berry, C. R., \& Glaeser, E. L. (2005). The divergence of human capital levels across cities. Papers in Regional Science, 84(3), 407-444.

Card, D., \& Lemieux, T. (2001). Can falling supply explain the rising return to college for younger men? A cohort-based analysis. The Quarterly Journal of Economics, $116(2)$, 705-746.

Chen, Z., Lu, M., \& Jin, Y. (2004). Regional differences of human capital and education development in China: An estimation of the panel data. The Journal of World Economy, 12, 25-31.

Chenn, B., \& Cao, W. (2013). From equal opportunity to equal results: The status Quo and Outlet of China's income distribution. Economic and Social Systems Comparison, 6, 44-59.

Chens, Y., Wang, Z., \& Wei, Z. (2004). Income inequality and its changes of Chinese urban residents in the 1990sregional factors and the role of human capital in it. Economic Science, 26(6), 16- 25

Chiswick, B. R. (1971). Earning inequality and economic development. Quarterly Journal of Economics, 85, 21-39.

Fan, C. S. (2003). Human capital, study effort, and persistent income inequality. Review of Development Economics, 7(2), 311326.

Galor, O., \& Zeira, J. (1993). Income distribution and macroeconomics. The review of Economic Studies, 60(1), 35-52.

Ge, Y. (2007). Research on the heterogeneity of education return. Southern Economy, 4, 11-21.

Gregorio, J. D., \& Lee, J. W. (2002). Education and income inequality: new evidence from cross-country data. Review of Income and Wealth, 48(3), 395-416.

Hou, F. (2004). Study on rural human capital return rate in China. Economic Research, 12.

Huang, Z., \& Yao, X. (2009). Research on gender differences in educational return rate. World Economy, 7, 74-83.

Li, S. (2005). Research group of China income distribution research institute, Beijing Normal University. Paper presented at the Research on the Dynamic Change of Chinese Residents' Property Distribution[C]// International Symposium on Rural Economic and Regional Sustainable Development in Western China and China Western Development Research Consortium Annual Meeting.

Li, S., \& Ding, S. (2003). The long-term trend of China's urban education return rate. China Social Sciences, 6, 58-72.

Li, S., \& Li, T. (2010). Can the Kuznets hypothesis explain China's income gap. Economic Theory and Business Management, 3 , 5-10.

Li, S., \& Ma, X. (2006). An empirical analysis of gender wage differences and occupational segmentation of Chinese urban workers. Chinese Journal of Population Science, 5, 2-13.

Li, S., \& Song, J. (2010). The expansion of China's urban employment income gap and its causes. Economics, 10, 4-10.

Lihua, H., \& Wang, Z. (2006). The economic cost and welfare consequences of the college entrance examination-a generational overlap model. Education $\S^{\circ}$ Economy, 4, 15-22.

Liu, Y., \& Xu, Y. (2007). A co-integration study on the gap between urban and rural education and the income input of urban and rural residents in China-based on data analysis from 1990 to 2005. Education and Economy, 4, 42-46.

Londono, J. L. (1990). Kuznetsian tales with attention to human capital. Paper presented at the Paper Presented at the Third Inter-American Seminar in Economics, Rio de Janeiro, Brazil.

Lu, M., Chen, Z., \& Wan, G. (2005). Inequality out of scarcity-interactions of China's income Gap, investment, education and growth. The Journal of Economic Research, 12, 4-14.

Mincer, J. S. (1974). Experience and earnings. New York: Columbia University Press.

Papanicolaou, J., \& Psacharopoulos, G. (1979). Socioeconomic background, schooling and monetary rewards in the United Kingdom. Economica, 46(184), 435-439.

Park, K. H. (1996). Educational expansion and educational inequality on income distribution. Economics of Education Reviere, 15(1), 51-58.

Patrinos, H. A. (1995). Socioeconomic background, schooling, experience, ability and monetary rewards in Greece. Economics of Education Review, 14(1), 85-91.

Patrinos, H. A., \& Sakellariou, C. (2006). Economic volatility and returns to education in Venezuela: 1992-2002. Applied Economics, 38(17), 1991-2005.

Psacharopoulos, G. (1977). Unequal access to education and income distribution. De Economist, 125(3), 383-392.

Psacharopoulos, G., \& Patrinos, H. A. (2004). Returns to investment in education: A further update. Education Economics, 12(2), $111-134$.

Ram, R. (1990). Educational expansion and schooling inequality: International evidence and some implications. The Revierw 
of Economics and Statistics, 72(2), 266-274.

Schultz, T. W. (1960). Capital formation by education. Journal of Political Economy, 68(6), 571-583.

Shiyan, G., \& Luo, R. (2009). Study on the age difference of urban education return rate in China. Statistics \& Decision, 18, 76-78.

Sun, T. (2015). Empirical study on the income distribution gap and educational inequality. Research on Financial and Economic Issues, 8, 69-74.

Sylwester, K. (2000). A model of public education and income inequality. Working Paper. Carbondale: Southern Illinois University.

Thomas, V., Wang, Y., \& Fan, X. (2003). Measuring education inequality: Gini coefficients of education for 140 countries, 1960-2000. Journal of Education Planning and Administration, 17(1), 5-33.

Tinbergen, J. (1972). The impact of education on income distribution. Review of Income and Wealth, 18(3), 255-265.

Wang, X., \& Gang, F. (2005). Analyzing the trends and factors of China's income gap. Economic Research Journal, $24-36$.

Wangg, M. (2009). Education return and urban and rural education resource allocation. World Economy, 5, 3-17.

Wangs, A., \& Xu, X. (2008). An empirical study on the influencing factors of regional education gap. Journal of Nanjing Normal University (Social Science Edition)(4).

Welch, F. (1979). Effects of cohort size on earnings: The baby boom babies' financial bust. Journal of Political Economy, $87(5$, Part 2), S65-S97.

Winegarden, C. R. (1979). Schooling and income distribution: Evidence from international data. Economica, 46(181), 83-87.

Xing, C. (2008). Regression, educational return and income gap. Statistical Research, 25(5), 43-49.

Yang, J., Huang, X., \& Li, X. (2008). The educational inequality and the gap in income distribution: an empirical analysis on China. Management World, 1, 38-47.

Yangs, J., \& Huang, W. (2010). The internal mechanism of educational inequality and income distribution gap-based on the analysis of Chinese provincial panel data. Journal of Public Administratio, 7(3), 75-82.

Yao, X., Huang, Z., \& Su, Z. (2007). Family background and educational return rate. China Labor Economy, 6, 19-29.

$\mathrm{Yu}, \mathrm{L}$. (2006). Institutional change and educational inequality: Mechanisms in educational stratification in Urban China (1966-2003) [J]. Social Sciences in China, 4, 97-109.

Yuan, C., \& Zhang, L. (2009). Observation on the university income of children from low-income families. Economic Research, 5, 42-51.

Yuu, X., \& Zhou, J. (2015). Differences in family background of educational return rate. Education Science, 31(3), 16-25.

Zhang, C., \& Xue, X. (2008). Wage difference between state-owned and non-state-owned sectors and contribution of human capital. Economic Research, 4, 15-25.

Zhao, L. (2006). Research on the educational rate of return in rural China. China Social Sciences, 3, 98-109.

Zhu, N. (2003). On the effect of education on the production activities and income of rural households in China. China Population Science, 2, 17-26. 